\title{
Efektifitas Self Management Module dalam Mengatasi Morning Sickness
}

\author{
Lutfatul Latifah, Nina Setiawati, Eti Dwi hapsari \\ Jurusan Keperawatan FIKes UNSOED \\ Email:latifah.lutfatul@gmail.com
}

\begin{abstract}
Abstrak
Perubahan fisiologis pada kehamilan trimester pertama banyak menimbulkan keluhan, salah satunya adalah mual muntah. Ibu hamil yang mengalami mual muntah kebanyakan tidak mengetahui cara mengatasinya, hanya membiarkan saja ketika keluhan itu datang. Ibu baru pergi ke tempat pelayanan kesehatan ketika keluhan tersebut sudah mengganggu aktifitas. Mual muntah pada kehamilan seharusnya dapat diatasi dengan perubahan perilaku. Self management module dapat merubah perilaku dengan informasi untuk mengatasi mual muntah tanpa penggunaan terapi farmakologi. Penelitian ini bertujuan untuk mengetahui pengaruh self management module dalam mengatasi morning sicknes pada ibu hamil. Penelitian ini merupakan penelitian pre experiment dengan rancangan pre and posttest one group. Data dikumpulkan melalui pengukuran frekuensi mual muntah menggunakan (PUQE)-24. Responden yang terlibat sebanyak 30 orang. Data dianalisis menggunakan uji Wilcoxon. Hasil uji normalitas menunjukkan data terdistribusi tidak normal. Rerata nilai pretest $=6,52$ $(\mathrm{SD}=1,947)$ dan posttest $=4,52(\mathrm{SD}=1,895)$. Terdapat 27 responden yang mengalami penurunan skor, dua orang mengalami peningkatan skor, dan satu orang memiliki skor yang sama saat pretest maupun posttest. Perbedaan nilai pretest dan posttest dianalisis menggunakan uji Wilcoxon, sehingga diperoleh nilai signifikansi 0,000 $(\mathrm{p}<0,05)$. Terdapat perbedaan skor PUQE sebelum dan sesudah pemberian self management module morning sickness. Self management module morning sickness efektif dalam mengatasi morning sickness pada ibu hamil.
\end{abstract}

Kata kunci: Morning sickness, PUQE, self management module, terapi nonfarmakologi.

\section{Effectiveness Self Management Module in Overcoming Morning Sickness}

\begin{abstract}
Physiological changes during the first-trimester prenatal period may cause many problems, one of which is morning sickness. Many pregnant women having morning sickness did not know the solution. Mostly, they ignored it. They went to the health services when the problem got worse and interfered their activities. After all, morning sickness should be solved by behavior change. Self-management module can vary the behavior by giving information to overcome morning sickness without pharmacological therapy. A quantitative research with pre-experiment, pre and post-test one group design, this study, therefore, aims at determining the effect of self-management module in overcoming morning sickness on pregnant women. Data were collected by Pregnancy-Unique Quantification of Emesis (PUQE)-24 scoring system. The study participants were 30 pregnant women. Data were analyzed by Wilcoxon. Based on the normality test results, data distribution was abnormal. The mean value of pretest $=6.52$ $(\mathrm{SD}=1.947)$ and post-test $=4.52(\mathrm{SD}=1.895)$. There were 27 respondents who experienced a decline in scores, two of whom increased scores and one had similar pretest and posttest scores. Differences in the pretest and posttest values using Wilcoxon test significance value of $0.000(p<0.05)$. There was a difference PUQE scores before and after administration of self-management module morning sickness. It could be concluded that the self management module of morning sickness is effective in overcoming pregnant women's morning sickness.
\end{abstract}

Keywords: Morning sickness, non-pharmacological therapy, PUQE, self management module. 
Lutfatul Latifah : Efektifitas Seif Management Modul dalam mengatasi Morning Sickness

\section{Pendahuluan}

Wanita hamil mengalami mual dan muntah terutama pada trimester pertama yaitu saat usia kehamilan sekitar 6 dan 12 minggu, tetapi sekitar $20 \%$ wanita hamil dapat mengalami mual muntah hingga usia kehamilan 20 minggu (Jewell, 2003). Koren et al. (2005) menyatakan bahwa mual dan muntah merupakan gangguan medis tersering selama kehamilan. Jewell dan Young (2003) mengidentifikasi angka kejadian mual antara $70-85 \%$, dengan sekitar setengah dari persentase ini mengalami muntah. Menurut O'Brien dan Naber (1992), lebih dari 70\% wanita hamil yang mengalami mual dan muntah selama kehamilan, 28\% diantaranya melaporkan bahwa mual dan muntah tersebut menyebabkan aktifitasnya terganggu.

Mual dan muntah pada kehamilan, umumnya dikenal sebagai "morning sickness" yang memengaruhi sekitar $80 \%$ wanita hamil (Matthews et al., 2010). Wanita hamil yang mengalami mual muntah kebanyakan tidak mengetahui cara mengatasi keluhan mual muntah. Saat keluhan itu datang, mereka hanya membiarkannya saja dan tetap melakukan aktivitasnya. Apabila keluhan sudah mengganggu aktivitas, mereka akan pergi ke Rumah Sakit, Klinik, atau Puskesmas terdekat dan mereka akan diberi obat antimuntah. Meskipun aman bagi janin, sebagian antiemetik kontraindikasi terhadap kehamilan (Mazzotta \& Magee, 2000). Penggunaan obat untuk ibu hamil perlu diperhatikan karena terjadi banyak perubahan farmakokinetik maupun farmakodinamik obat saat terjadi kehamilan.

Mual dan muntah saat hamil sebenarnya adalah gangguan yang ringan, kondisi ini pada kenyataannya dapat diatasi dengan pengendalian diri (Matthews et al., 2010). Kusmana, Latifah, dan Susilowati (2012) melakukan penelitian tentang pengaruh hipnoterapi dalam menurunkan frekuensi mual dan muntah pada ibu hamil, hasil penelitian menyatakan ada pengaruh hipnoterapi terhadap penurunan frekuensi mual dan muntah. Hipnoterapi yang dilakukan berisi penguatan dan pengendalian diri terhadap keinginan mual muntah dengan cara terapis memberikan kata-kata sugestif agar ibu hamil secara alam bawah sadar mengendalikan organ pencernaannya untuk tidak mengalami mual dan muntah. Selain pengendalian diri, mual muntah juga dapat diatasi dengan menciptakan perilaku untuk mengurangi keluhan (Ward \& Hisley, 2009). Menciptakan perilaku untuk hidup sehat sesuai kondisi pasien merupakan bagian dari self management.

Self management merupakan istilah yang digunakan pada promosi dan pendidikan kesehatan serta berguna bagi pasien yang mengalami gangguan fisik maupun psikologis melalui perbaikan perspektif diri dan kesejahteraan pasien (Kate \& Halsted, 2003). Kondisi morning sickness, selain disebabkan oleh hormon kehamilan, juga karena kondisi psikologis ibu hamil itu sendiri (Littleton \& Engebretson, 2002). Beberapa penelitian membuktikan bahwa self management dapat memperbaiki kondisi pasien (Bourbeau et al., 2003; Buml \& Garret, 2005; Lorig, Sobel, Ritter, Laurent, \& Hobbs, 2001), tetapi belum ada penelitian self management untuk mengatasi morning sickness. Terdapat setidaknya dua hal dalam self management, yaitu (1) manajemen pengobatan dan (2) mempertahankan, merubah, dan menciptakan perilaku hidup sehat yang baru sesuai dengan kondisi pasien (Corbin \& Straus dalam Kate \& Halsted, 2003).

Self management morning sickness mengadopsi konsep dari Corbin dan Straus dalam Kate dan Halsted (2003) tersebut, yang dituangkan dalam bentuk modul berisi pengetahuan dasar morning sickness, kebiasaan dan intervensi yang dapat mengurangi morning sickness, diet untuk mencegah morning sickness, dan menu makanan sehat yang dapat disusun sendiri oleh ibu. Modul yang disusun sendiri oleh peneliti ini bertujuan agar ibu hamil dapat mengedukasi diri sendiri sehingga mampu untuk mengatur hidup sendiri, mengatur tujuan, dan menyediakan penguat untuk diri sendiri dalam menangani mual muntah yang dialami.

\section{Metode Penelitian}

Penelitian ini dilaksanakan pada bulan Mei sampai September 2014 di wilayah kerja Puskesmas Kembaran, Kecamatan 
Lutfatul Latifah : Efektifitas Seif Management Modul dalam mengatasi Morning Sickness

Kembaran, Kabupaten Banyumas. Sampel dalam penelitian ini sejumlah 30 responden yang memenihi kriteria inklusi dan eksklusi. Kriteria inklusi pada penelitian ini adalah ibu hamil yang mengalami mual muntah. Sedangkan kriteria eksklusinya adalah ibu hamil yang mengalami hiperemesis gravidarum dan gastritis. Penelitian ini bertujuan untuk mengetahui pengaruh self management morning sickness module dalam mengatasi morning sickness dengan melihat penurunan skor mual muntah dalam 24 jam terakhir.

Penelitian ini menggunakan 2 instrumen, yaitukuesionerdata demografidanPregnancyUnique Quantification of Emesis and Nausea (PUQE)-24 scoring system. Kuesioner data demografi berisi 5 pertanyaan, yaitu usia, pendidikan, pekerjaan, usia kehamilan, dan status gravida responden. Instrumen Pregnancy-Unique Quantification of Emesis and Nausea (PUQE) scoring system adalah instrumen penelitian yang dikembangkan oleh Koren et al. (2002) dan telah divalidasi oleh Koren et al. (2005) kemudian digunakan dalam beberapa penelitian (Lacasse et al., 2008; Kusmana, Latifah, \& Susilowati, 2012). PUQE scoring system yang digunakan tersebut adalah untuk mengukur tingkat keparahan mual dan muntah pada kehamilan dalam 12 jam sehingga disebut PregnancyUnique Quantification of Emesis (PUQE)12 hour. Ebrahimi, Mastepe, Bournissen, dan Koren (2009) kemudian memodifikasi PUQE-12 hour menjadi PUQE-24. PUQE24 adalah sistem penilaian untuk mengukur tingkat keparahan mual muntah kehamilan dalam 24 jam. Skor PUQE untuk setiap pasien dihitung dengan menggunakan tiga kriteria untuk menilai keparahan mual muntah selama kehamilan (jumlah jam merasakan mual, jumlah episode muntah, dan jumlah episode muntah kering dalam 24 jam terakhir). Skor PUQE dihitung dengan menambahkan nilainilai dari masing-masing kriteria, dan dapat berkisar dari minimal 1 sampai maksimal 15. Penelitian ini menggunakan instrumen penelitian PUQE-24. Pengukuran skor PUQE dilakukan 2 kali, yaitu sebelum memberikan modul dan setelah 2 minggu pemberian modul. Diantara pengukuran dilakukan juga monitoring terhadap penggunaan modul yaitu seminggu setelah pemberian modul.

Modul self management morning sickness dikembangkan sendiri oleh peneliti. Modul ini berisi informasi tentang perubahan fisik dan psikologis yang berkaitan dengan morning sickness, pengetahuan dasar tentang morning sickness (pengertian dan penyebab), serta penanganan morning sickness (kebiasaan dan intervensi yang dapat mengurangi morning sickness, diet untuk mencegah morning sickness dan menu makanan sehat).

Analisis data untuk mengetahui pengaruh pemberian self management module terhadap frekuensi mual muntah dilakukan dengan melihat skor PUQE-24 menggunakan uji Wilcoxon. Penurunan skor PUQE diketahui dengan melihat selisih rerata penurunan skor pretest dan posttest.

Penelitian ini dilaksanakan melalui 2 tahap, yaitu persiapan dan pelaksanaan. Pada tahap pelaksanaan dilakukan pengumpulan data demografi responden, mengukur skor

Table 1 Motherisk Pregnancy-Unique Quantification of Emesis and Nausea (PUQE)-24 Scoring System

\begin{tabular}{|c|c|c|c|c|c|}
\hline $\begin{array}{l}\text { Dalam } 24 \text { jam terakhir, untuk } \\
\text { berapa lama Anda merasa mual } \\
\text { atau tidak nyaman pada perut? }\end{array}$ & $\begin{array}{l}\text { Tidak sama } \\
\text { sekali }\end{array}$ & 1 jam atau kurang & 2-3 jam & 4-6 jam & $>6 \mathrm{jam}$ \\
\hline Score & 1 & 2 & 3 & 4 & 5 \\
\hline $\begin{array}{l}\text { Dalam } 24 \text { jam terakhir, apakah } \\
\text { Anda muntah-muntah? }\end{array}$ & Tidak muntah & 1-2 kali & 3-4 kali & 5-6 kali & $\geq 7$ kali \\
\hline Score & 1 & 2 & 3 & 4 & 5 \\
\hline $\begin{array}{l}\text { Dalam } 24 \text { jam terakhir, berapa kali } \\
\text { Anda telah mengalami muntah } \\
\text { kering? }\end{array}$ & Tidak pernah & $1-2$ kali & 3-4 kali & $5-6$ kali & $\geq 7 \mathrm{kali}$ \\
\hline Score & 1 & 2 & 3 & 4 & 5 \\
\hline
\end{tabular}


Lutfatul Latifah : Efektifitas Seif Management Modul dalam mengatasi Morning Sickness

PUQE-24, dan memberikan modul morning sickness untuk dipelajari oleh responden. Setelah satu minggu, peneliti kembali mengunjungi responden untuk memastikan responden melakukan intervensi seperti yang tertulis di dalam modul. Satu minggu kemudian dilakukan pengukuran kembali skor PUQE-24.

\section{Hasil Penelitian}

1. Karekteristik Responden

Pada tabel 3 dapat diketahui bahwa nilai PUQE pada ibu hamil yang mengalami mual muntah sebelum diberikan self management module morning sickness memiliki nilai ratarata 6,52 dengan nilai maksimum 11 dan

Tabel 2 Karekteristik Responden

\begin{tabular}{|c|c|c|}
\hline Karekteristik & $\mathbf{N}$ & $\%$ \\
\hline \multicolumn{3}{|l|}{ Usia } \\
\hline a. $<20$ tahun & 2 & 6,67 \\
\hline b. 20-35 tahun & 27 & 90,00 \\
\hline c. $>35$ tahun & 1 & 3,33 \\
\hline \multicolumn{3}{|l|}{ Pendidikan } \\
\hline a. SD & 6 & 20,00 \\
\hline b. SMP & 12 & 40,00 \\
\hline c. SMA & 10 & 33,33 \\
\hline d. S1 & 2 & 6,67 \\
\hline \multicolumn{3}{|l|}{ Pekerjaan } \\
\hline a. IRT & 23 & 76,67 \\
\hline b. Pedagang & 2 & 6,67 \\
\hline c. Karyawan & 5 & 16,67 \\
\hline \multicolumn{3}{|l|}{ Usia Kehamilan } \\
\hline a.1-12 minggu & 18 & 60,00 \\
\hline b.13-24 minggu & 12 & 40,00 \\
\hline c. $>25$ minggu & 0 & 0,00 \\
\hline \multicolumn{3}{|l|}{ Status Gravida } \\
\hline a.Primigravida & 12 & 40,00 \\
\hline b.Multigravida & 18 & 60,00 \\
\hline \multicolumn{3}{|l|}{ Gejala Morning Sickness } \\
\hline \multicolumn{3}{|l|}{ Pretest } \\
\hline a.Tidak ada & 0 & 0 \\
\hline b.Ringan & 22 & 73,33 \\
\hline c.Sedang & 8 & 26,67 \\
\hline d.Berat & 0 & 0 \\
\hline \multicolumn{3}{|l|}{ Posttest } \\
\hline a. Tidak ada & 9 & 30 \\
\hline b. Ringan & 18 & 60 \\
\hline c. Sedang & 3 & 10 \\
\hline d. Berat & 0 & 0 \\
\hline
\end{tabular}


Lutfatul Latifah : Efektifitas Seif Management Modul dalam mengatasi Morning Sickness

2. Nilai Pregnancy-Uniqe Quantification of Emesis and Nausea (PUQE)-24 Sebelum dan Sesudah Diberikan Self Management Module Morning Sickness

Tabel 3 Nilai Pregnancy-Uniqe Quantification of Emesis and Nausea (PUQE)-24 Sebelum dan Sesudah Diberikan Self Management Module Morning Sickness

\begin{tabular}{ccccc}
\hline Variabel & Mean & SD & Minimum & Maksimum \\
\hline Pretest & 6,52 & 1,947 & 4 & 11 \\
Posttest & 4,52 & 1,895 & 3 & 12 \\
\hline
\end{tabular}

3.Pengujian Hipotesis

Uji Wilcoxon digunakan karena data tidak memenuhi syarat uji parametrik. Hasil analisis tercantum pada tabel 4 dan 5 .

Tabel 4 Wilcoxon Signed Ranks Test

\begin{tabular}{ccccc}
\hline & N & Mean Rank & Sum of Ranks \\
\hline Posttest - Pretest & Negative Ranks & $27 \mathrm{a}$ & 15,76 & 425,50 \\
& Positive Ranks & 2b & 13,17 & 39,50 \\
& Ties & 1c & & \\
& Total & 30 & & \\
& & & \\
\hline
\end{tabular}

Katerangan :

$\begin{array}{ll}\text { a. } & \text { Posttest }<\text { Pretest } \\ \text { b. } & \text { Posttest }>\text { Pretest }\end{array}$

$\begin{array}{ll}\text { b. } & \text { Posttest }>\text { Pretest } \\ \text { c. } & \text { Posttest }=\text { Pretest }\end{array}$

Tabel 5 Hasil Analisis Statistik dengan WIlcoxon

\begin{tabular}{lccc}
\hline \multicolumn{1}{c}{ Variabel } & Mean & SD & Nilai $p$ \\
\hline Sebelum & 6,52 & 1,947 & 0,000 \\
Sesudah & 4,52 & 1,895 & \\
\hline
\end{tabular}

nilai minimumnya 4. Nilai PUQE setelah self management module morning sickness memiliki nilai rata-rata 4,52 dengan nilai maksimum 12 dan nilai minimum 3 .

\section{Pembahasan}

Ditinjau dari karekteristik responden (Tabel 1), usia terbanyak berada pada rentang 20-35 tahun. Tidak jauh berbeda dengan penelitian yang dilakukan oleh Shrim, Weisz, Gindes, Dulitzky, dan Almog (2010), rata-rata usia ibu hamil yang mengalami mual muntah adalah 29 tahun. Sari (2013) menjelaskan tentang hubungan antara usia ibu hamil dengan kejadian hiperemesis gravidarum, pada ibu hamil yang berusia kurang dari 20 tahun, rahim belum berfungsi secara optimal.
Secara psikologis, ibu hamil yang berumur kurang dari 20 tahun belum siap menerima kehamilannya, belum matang emosinya, cenderung labil, dan belum siap untuk menjadi orang tua. Hal ini dapat memicu konflik mental atau stres yang membuat ibu tidak memperhatikan asupan nutrisinya yang berlanjut pada mual dan muntah. Sedangkan mual muntah yang terjadi pada ibu hamil yang berusia diatas 35 tahun dikarenakan oleh kondisi psikologis akibat takut memiliki anak di usia tua, sehingga perubahan emosi ini memicu muntah yang berlebihan.

Tingkat pendidikan responden terbanyak adalah SMP sebesar 40\%. Hasil penelitian ini tidak sesuai dengan penelitian yang dilakukan oleh Suwarnisih (2011), dimana didapatkan data pendidikan ibu hamil yang mengalami mual muntah yang terbanyak adalah lulus 
Lutfatul Latifah : Efektifitas Seif Management Modul dalam mengatasi Morning Sickness

SMA sejumlah 18 responden (45,5\%). Hal ini dimungkinkan karena wilayah tempat tinggal responden pada penelitian ini merupakan wilayah pedesaan dan jenjang sekolah yang terdekat dengan wilayah tersebut paling tinggi adalah SMP.

Karekteristik responden berdasarkan pekerjaan, menunjukkan bahwa responden dalam penelitian ini adalah ibu rumah tangga, pedagang, dan karyawan swasta. Hampir seluruh responden merupakan ibu rumah tangga yaitu sejumlah 23 orang $(76,67 \%)$. Hasil penelitian ini berbeda dengan penelitian yang dilakukan Suwarnisih (2011), dimana karyawan swasta merupakan profesi yang banyak didapatkan dalam penelitiannya. Sedangkan dalam penelitian yang dilakukan Elsa dan Pertiwi (2012), didapatkan hasil yang sama dengan penelitian ini yaitu ibu rumah tangga merupakan mayoritas ibu hamil yang mengalami mual muntah yaitu $32,14 \%$.

Pekerjaan berhubungan dengan kondisi sosial ekonomi yang juga memengaruhi pola makan, aktifitas, dan stres pada ibu hamil. Apabila seorang ibu ikut membantu penghasilan dalam rumah tangga, maka pada saat hamil mereka lebih banyak mengeluarkan tenaga dan pikiran. Sehingga efeknya dapat berpengaruh pada kondisi fisik dan psikologis. Kondisi tersebut dapat menyebabkan stimulasi pada pusat muntah di otak yang menyebabkan mual muntah. Selain itu, perjalanan ke tempat kerja yang mungkin terburu-buru di pagi hari tanpa waktu yang cukup untuk sarapan, dapat menyebabkan mual dan muntah (Tiran, 2009).

Sesuai dengan tujuan penelitian, hasil penelitian inimenggambarkan kecenderungan penurunan skor PUQE-24 dari sebelum pemberian dan sesudah pemberian modul. Rerata skor PUQE-24 mengalami penurunan sebesar 2 poin yaitu sebesar 6,52 dengan standar deviasi 1,947 sebelum perlakuan, dan 4,52 dengan standar deviasi 1,895 setelah perlakuan. Hasil analisis statistik dengan uji Wilcoxon menunjukkan sejumlah 27 reponden $(90 \%)$ mengalami penurunan skor PUQE-24 dengan nilai $p=0,000$. Hal ini membuktikan bahwa terdapat pengaruh yang signifikan pada pemberian self management module dalam mengatasi morning sickness.

Kohen et al. (2005) mengkatagorikan tingkat keparahan mual muntah dalam kehamilan menjadi 3 katagori. Nilai skor 0-3 tidak ada gejala, nilai skor 4-6 gejala ringan, nilai skor 7-12 sedang, dan nilai skor $\geq 13$ katagori berat. Berdasarkan karekteristik frekuensi morning sickness, sebelum perlakuan terdapat $73,33 \%$ responden mengalami mual muntah ringan dan $26,67 \%$ mengalami mual muntah sedang. Tidak ada responden yang mengalami mual muntah berat. Setelah perlakuan, responden yang mengalami mual muntah ringan menjadi $60 \%$, sedang $10 \%$ dan $30 \%$ menjadi tidak mengalami mual muntah. Dari 22 responden yang mengalami mual muntah katagori ringan saat pretest, sebanyak 19 responden mengalami penurunan skor, 2 responden mengalami peningkatan, dan 1 responden memiliki skor tetap. Dari 19 responden yang mengalami penurunan skor, 7 responden menjadi tidak mengalami mual muntah sama sekali, dan 12 responden tetap mengalami mual muntah ringan tetapi skornya berkurang. Sedangkan 8 responden yang mengalami mual muntah dengan katagori sedang setelah diberikan perlakuan, sebanyak 2 responden menjadi tidak mengalami mual muntah sama sekali, 5 responden mengalami penurunan skor menjadi kategori mual muntah ringan, dan 1 responden tetap mengalami mual muntah sedang tetapi skornya berkurang.

Hasil uji statistik Wilcoxon menunjukkan perbedaan yang signifikan antara skor PUQE sebelum pemberian modul self management morning sickness dan sesudah pemberian. Hal ini menunjukkan bahwa terdapat pengaruh modul self management morning sickness terhadap penurunan frekuensi mual muntah pada ibu hamil. Penurunan skor PUQE sebelum dan sesudah perlakuan pada ibu yang mengalami morning sickness katagori sedang lebih besar dibandingkan dengan katagori ringan. Hal ini dibuktikan dengan penurunan pada katagori sedang sebesar $50 \%$, sementara pada katagori ringan hanya $21,3 \%$. Walaupun terdapat perbedaan, akan tetapi modul ini sama-sama berpengaruh terhadap penurunan skor PUQE, sehingga dapat disimpulkan bahwa modul self management ini efektif dalam mengatasi morning sickness pada ibu hamil.

Penggunaan modul self management morning sickness untuk menurunkan 
Lutfatul Latifah : Efektifitas Seif Management Modul dalam mengatasi Morning Sickness

frekuensi mual muntah pada ibu hamil baru pertama kali diteliti di Indonesia. Namun, modul self management sebenarnya sudah diterapkan pada beberapa perawatan mandiri penyakit kardiovaskular dan skizofrenia.

Metode perawatan self management sudah pernah diteliti pengaruhnya pada penyakit kronis yaitu penyakit kardiovaskuler, diabetes melitus, penyakit paru obstruktif kronik, dan penyakit skizofrenia. Pasien diabetes yang mengikuti program self management terbukti secara signifikan mengalami perbaikan pada keadaan klinisnya (penurunan gula darah), dapat mencapai target perawatan diri, dan merasa puas dengan pelayanan kesehatan (Buml \& Garret, 2005). Pasien dengan penyakit kronik secara umum mengalami peningkatan kesehatan dan penurunan jumlah kunjungan ke rumah sakit dalam satu tahun setelah melakukan self management (Lorig, Sobel, Ritter, Laurent, \& Hobbs, 2001). Penelitian pada penyakit paru obstruktif menahun (PPOM) juga memperlihatkan hasil yang sama postitifnya. Pada pasien yang mengikuti program self management mengalami penurunan keparahan penyakit sebanyak $39,8 \%$, penurunan jumlah kunjungan ke rumah sakit sebanyak $57,1 \%$, penurunan jumlah kunjungan ke dokter secara insidental sebanyak $58,9 \%$, dan penurunan kunjungan ke unit gawat darurat sebesar $41 \%$ (Bourbeau et al., 2003).

Self management menjadi salah satu istilah yang umum dipakai pada promosi kesehatan dan pendidikan kesehatan pasien. Self management sangat berguna bagi pasien terutamapasiendenganpenyakitkronisdimana hanya pasien yang dapat bertanggungjawab terhadap perawatan penyakitnya seharihari selama masa sakitnya. Pasien dengan penyakit kronis selain mengalami gangguan fisik, biasanya juga mengalami gangguan psikologis dan kesejahteraan. Oleh sebab itu, program self management seringkali berfokus untuk memperbaiki persepktif diri dan kesejahteraan pasien (Kate \& Halsted, 2003). Modul self management morning sickness ini berisi tentang beberapa intervensi untuk mengatasi mual muntah selama kehamilan, diantaranya adalah konsumsi minuman jahe, pengaturan makanan, mobilisasi bertahap saat pagi hari, akupresur, dan relaksasi.

Beberapa penelitian telah membuktikan bahwa produk jahe yang dapat berupa minuman maupun ekstrak, terbukti dalam mengatasi mual dan muntah selama kehamilan (Saswita, 2011; Fischer-Rasmussen et al., 2001). McKinney et al. (2009) mengatakan bahwa pengaturan makan dengan makan porsi sedikit tetapi sering, menghindari makanan yang berminyak, lebih banyak mengkonsumsi protein dibandingkan dengan karbohidrat, dan memisahkan antara makan dan minum dapat mengurangi kejadian mual dan muntah selama kehamilan. Wentorf dan Dykes (2001) serta Artika (2006), menemukan bahwa akupresur dengan melakukan penekanan pada titik P6 (titik Neiguan) signifikan dalam mengurangi mual muntah selama kehamilan.

Selama jalannya penelitian tidak terdapat responden yang mengeluhkan kesulitan dalam menerapkan tugas dan anjuran pada modul self management morning sickness. Namun, beberapa responden menyatakan bahwa tidak semua tugas yang ada dalam modul bisa dilaksanakan, yang pertama adalah akupresur pada pagi hari. Responden tidak dapat melakukannya karena terkait pekerjaan reponden. Kedua adalah memakan biskuit sebelum beranjak dari tempat tidur, beberapa responden menyatakan bahwa tidak terbiasa untuk makan setelah bangun tidur.

Keterbatasan dalam penelitian ini adalah jumlah responden yang hanya memenuhi syarat uji non parametrik. Selain itu, peneliti hanya mengukur skor mual muntah saat posttest sehingga tidak diketahui tugas dan anjuran dalam modul self management morning sickness apa saja yang sudah dilakukan oleh responden. Peneliti juga tidak mengukur pengetahuan responden tentang mual muntah dan cara mengatasinya saat pre dan posttest sehingga peneliti tidak dapat mengukur sejauh mana responden memahami modul dan apakah responden melaksanakan tugas dan anjuran dengan cara yang benar.

\section{Simpulan}

Pada hasil penelitian ini, dapat disimpulkan bahwa self management module morning sickness dapat digunakan untuk mengatasi morning sickness. Walaupun penurunan skor PUQE lebih besar pada responden dengan 
Lutfatul Latifah : Efektifitas Seif Management Modul dalam mengatasi Morning Sickness

morning sickness katagori sedang, akan tetapi secara keseluruhan modul ini dapat digunakan pada responden dengan morning sickness katagori ringan maupun sedang. Hasil penelitian ini dapat berimplikasi terhadap pengembangan ilmu keperawatan, khususnya keperawatan maternitas, yaitu self management module mengenai morning sickness dapat diberikan sebagai acuan pada ibu hamil yang melakukan kunjungan ANC di berbagai pelayanan kesehatan.

Penelitian lebih lanjut diperlukan dengan melibatkan jumlah responden yang lebih besar dan area yang lebih luas. Selain itu juga perlu adanya kelompok kontrol yang homogen baik responden yang mengalami morning sickness katagori ringan maupun sedang. Penelitian selanjutnya dapat juga melihat perbedaan tingkat pengetahuan responden sebelum dan sesudah diberikan self management module serta mengidentifikasi tugas-tugas yang terdapat dalam self management module yang tidak dapat dipraktikan oleh responden.

\section{Daftar Pustaka}

Artika, P. (2006). Pengaruh akupresur pada titik perikardium 6 terhadap penurunan frekuensi muntah pada primigravida trimester pertama dengan emesis gravidarum (Tugas Akhir). Fakultas Kedokteran, Universitas Brawijaya, Malang.

Bourbeau, J., Julien, M., Maltais, F., Rouleau, M., Beaupré, A., \& Bégin, R. (2003). Reduction of hospital utilization in patients with chronic obstructive pulmonary disease. Arch Intern Med, 585-591.

Buml, B.M., \& Garret, D.G. (2005). Patient self management program of diabetes: Firstyear clinical, humanistic and economic outcomes. Journal of American Pharmachist Association, 130-137.

Ebrahimi, N., Maltepe, C., Bournissen, F.G., \& Koren, G. (2009). Nausea and vomiting of pregnancy: Using the 24-hour PregnancyUnique Quantification of Emesis (PUQE-24) Scale. J Obstet Gynaecol Can, 803-807.

Elsa, W.V., \& Pertiwi, H.W. (2012). Hubungan paritas ibu hamil trimester i dengan kejadian emesis gravidarum di Puskesmas Teras. Jurnal Kebidanan, IV(02).

Fischer-Rasmussen, W., Kjaer, S.K., Dahl, C., \& Asping, U. (1991). Ginger treatment of hyperemesis gravidarum. Eur $J$ Obstet Gynecol Reprod Biol. 4, 38(1), 19-24.

Jewell, D. (2003). Nausea and vomiting in early pregnancy. American Family Physician, 68(1), 143-4.

Jewell, D., \& Young, G. (2003). Interventions for nausea and vomiting in early pregnancy. Cochrane Database Syst Rev: CD000145.

Kate, R.L., \& Halsted , R.W. (2003). Self management education: History, definition, outcomes and mechanism. Ann Behav Med, $1-7$.

Koren, G., Boskovic, R., Hard, M., Maltepe, C., Navioz, Y., \& Einarson, A. (2002). Motherisk-PUQE scoring system for nausea and vomiting of pregnancy. American Journal of Obstetrics and Gynecology, 186 (5 suppl), S228 - S231.

Koren, G., Piwko, C., \& Ahn, E. (2005). Validation studies of the Pregnancy UniqueQuantification of Emesis (PUQE) scores. PMID: 16147725 (PubMed - indexed for MEDLINE).

Kusmana, Y.H., Latifah, L., \& Susilowati, I. (2012). Pengaruh hipnoterapi terhadap mual dan muntah pada ibu hamil trimester pertama di Puskesmas Baturaden 2 (Skripsi). Universitas Jenderal Soedirman, Purwokerto.

Lacasse, A., Rey, E., Ferreira, E., Morin, C. \& Berard, A. (2008). Validity of a Modified Pregnancy-Unique Quantification of Emesis and Nausea (PUQE) scoring index to asses severity of nausea and vomiting of pregnancy. Am J Obstet Gynecol;198:71.e1-71.e7.

Littleton, L.Y., \& Engebretson, J.C. (2002). Maternal, neonatal and woman's health nursing. New York: Delmar.

Lorig, K.R., Sobel, F.S., Ritter, P.R., 
Lutfatul Latifah : Efektifitas Seif Management Modul dalam mengatasi Morning Sickness

Laurent, D., \& Hobbs, M. (2001). Effect of management program on patient with chronic disease. American College of Phsycians.

Matthews, A., Dowswell, T., Haas, D.M., Doyle, M., \& O'Mathúna, D.P. (2010). Interventions for nausea and vomiting in early pregnancy. Cochrane Database Syst Rev; 9, CD007575.

Mazzotta, P., \& Magee, LA. (2000). A riskbenefit assessment of pharmacological and nonpharmacological treatments for nausea and vomiting of pregnancy. PubMed, 59(4), 781-800.

McKinney, E.S., James, S.R., Murray, S.S., \& Ashwil, J.W. (2009). Maternal-child nursing (3rd ed.). St. Louis, Missouri: Saunders Elsevier.

O'Brien, B., \& Naber, S. (1992). Nausea and vomiting during pregnancy: Effects on the quality of women's lives. Birth, 19(3), 138143.

Sari, S. (2013). Hubungan beberapa faktor risiko ibu hamil dengan hiperemesis gravidarum (Skripsi). Universitas Jambi, Jambi.
Saswita, Dewi, Y.I., \& Bayhakki. (2011). Efektifitas minuman jahe dalam mengurangi emesis gravidarum pada ibu hamil trimester I. Jurnal Ners Indonesia, 1(2).

Shrim, A., Welsz, B., Gindes, L., Dulitzki, M., \& Almog, B. (2010). Preferences of caregiver when experiencing nausea and vomiting during pregnancy. J. Perinat. Med., $38,157-160$.

Suwarnisih. (2011). Tingkat pengetahuan ibu tentang emesis gravidarum pada ibu hamil trimester I di Rb Bidan Sulastri Gond (Laporan Penelitian). Akademi Kebidanan Mitra Husada Karanganyar, Karanganyar.

Tiran, D. (2009). Mual dan muntah kehamilan. Jakarta: EGC.

Ward, S.K., \& Hisley, S.M. (2009). Maternalchild nursing care optimizing outcomes for mothers, children, \& families. Philadelphia: F.A. Davis Company.

Werntoft, E., \& Dykes, A.K. (2001). Effect of acupressure on nausea and vomiting during pregnancy. A randomized, placebocontrolled, pilot study. J Reprod Med., 46(9), 835-9. 